\title{
The Sad Case of Mr Watene
}

Here is a good teaching case:

J. L. Crammer, Reader in Biological Psychiatry, Maudsley Hospital

Mr Watene, aged 25, was put in prison for seven days on a charge of offensive behaviour, with a charge of robbery pending. On the third day he was recommended for transfer to a psychiatric hospital because he was sullen, depressed and uncommunicative; he had barricaded himself in his cell because he was scared of other prisoners, and he carried a knife for his protection, as he said. Two doctors wrote the order. One noted: 'It is very difficult to gain his attention. He cerebrates slowly, and replies to repeated questioning are in the main irrelevant.' The other said: 'It is not really possible to have a conversation with him, but he does indicate his fear of being left alone in the cell and wished me to stay with him. Says he is mixed up.'

He was admitted to hospital by the duty doctor, who got nothing out of him, and seemingly without further history or any physical examination wrote, 'patient considered to be dangerous-Yes, prob. impulsive ... Had barricaded himself in a cell with a knife.' He prescribed Mist. chloral $10-20 \mathrm{ml}$ nocte and 'Largactil' $100 \mathrm{mg}$. i.m. S.O.S. and/or paraldehyde 10-20 ml i.m. S.O.S. (si opus sit, 'if needed').

At the nurse's discretion he was then locked into a strongroom with a plastic chamber pot and a mattress on the floor: i.e. secluded. Next day his allotted doctor saw him, thought he looked suspicious and tense, but got little verbal out of him and felt a physical examination would be inadvisable. At the end of this interview Mr Watene spontaneously asked the doctor for a cigarette: he did not get one, but was promised one when more staff were available. Notes by both doctor and nurse repeatedly and chiefly stated: 'could be dangerous'; 'totally unpredictable' and the diagnosis 'paranoid reaction'!

The following day the staff thought he was worse because he was now restless in his room and backed away when his breakfast was brought in. The doctor, without further examination, gave him ECT that afternoon-unmodified, because of the difficulties of giving an injection, and after a violent struggle in the room. A seclusion order was now signed. The patient was given $25 \mathrm{mg}$. 'Modecate'. Twenty $\mathrm{ml}$ paraldehyde was given after ECT, and repeated thrice at roughly two-hour intervals. Next day the patient received two more unmodified ECT in the morning, and started haloperidol syrup $20 \mathrm{mg}$.: three doses that day, one next morning, and then two-hourly from $4 \mathrm{pm}$ that afternoon and all the next two days, and at 2.0,4.0 and 6.0 am on the final day. At 9.0 am on that day he received his 5th ECT, modified with 'brietal' this time, and died shortly after. Postmortem findings were trivial and the conclusion was that death may have been due to cardiac arrhythmia following ECT, or possibly following the $660 \mathrm{mg}$. haloperidol administered in just under four days.

This death, in New Zealand, naturally led to considerable public disquiet, and a Government inquiry has just published its very detailed findings, of which the above is a very brief and incomplete account (Report of the Committee of Inquiry into Procedures at Oakley Hospital and Related Matters, January 1983). It is a sad and not unfamiliar story. We know it in England, and doubtless it happens round the world. It happens more often than meets the headlines, and in various grades of severity. It should never happen at all. It would be educative for trainees to list the failures in this case, not only by the ward staff but by the consultants, the committees, and the Health Board of Government. It is the rulers who decide how little money shall be spent, how few staff employed, who are prepared to take on untrained ignorant pairs of hands and not offer them some training, who do not understand the importance of good staff morale for proper work, or how to raise morale. Low morale was the basis of the events at Oakley Hospital, and low morale can appear anywhere.

What characterized Mr Watene's case is that the staff were frightened of him. The doctor was nervous of spending time with him or touching him, the nurses were expecting an unpleasant fight at any moment. He arrived labelled dangerous and violent, and all professional knowledge flew out of the window. Nobody stopped to consider that he might be frightened too. He had asked for someone to stay with him, but they isolated him. He asked for a cigarette but did not get one. Nothing of what was happening was explained to him. The staff were prepared to fight him to give him an intramuscular injection or straight ECT, but not to give an anaesthetic or a physical examination, and when he resisted their unexplained actions, that only proved how dangerous he was.

It is my experience that people are often light-heartedly labelled violent - in GPs' letters, social work reports and so on-and this often upsets hospital staff. A positive effort is needed to subdue the anxiety then aroused and the poor treatment likely to follow. One must always ask for detailed evidence of the violence: sometimes it turns out to mean a bit of shouting, or throwing a cup on the floor, or no actual act but merely someone's suspicion. The situation of violent acts is very important, because it can have been provocative, or the patient may have recognisable phases of endogenous greater irritability. Uncommunicative, possibly paranoid, people are often frightened and need reassurance. Their confidence has to be gained by trying a succession of contacts, by talking about their hobbies, offering a cigarette, perhaps finding someone from their home territory to greet them. Everything should be fully explained to them without worrying whether they are taking it in. A full personal and social history quickly obtained from someone may be invaluable in seeing how to manage the patient without fear 
and struggles.

Mr Watene had a family but apparently no one at Oakley thought of contacting them.

Morale is sustained in part by working within a known framework. Doctors and nurses need clear-cut procedures which define the limits of each person's responsibility and do not impose what may prove an unfair or impossible burden on a relatively inexperienced or untrained person. The decision to seclude should never be just one nurse's thought. Drugs should never be prescribed simply S.O.S. or p.r.n. (pro re nata, 'as occasion arises') without stating for how many times in how many hours or days.

Let us try to learn something from these official hospital inquiries, and the deaths will not be entirely in vain.

\section{Correspondence}

\section{Provisions for consent to treatment in the new Mental Health Act}

DeAR SiRS

May I attempt to clarify the questions raised by Ms. Bridgit C. Dimond in her article 'Consent to Treatment by the Mentally Ill and Mentally Handicapped' (Bulletin, August 1983, 7, 145)?

The consent-to-treatment provisions in the Mental Health Act 1983 (Sections 57 and 58) apply to patients detained in hospital for the treatment of mental disorder. Section 57 (psychosurgery and the surgical implantation of hormones to reduce male sexual drive) is extended to informal patients. Section 58 applies to ECT and medicines given after the first three months of continuous detention. Treatments requiring the formalities required by these Sections may not otherwise be given. The exception to this rule is a situation of urgent necessity, when treatments otherwise controlled by Sections 57 and 58 may be given (for the reasons stated in Section 62).

Informal patients and patients on short-term Sections (not at this stage detained for treatment), i.e. Sections 4, 5(2), $5(4), 35,37(4), 135,136$, and conditionally discharged detained patients, do not come within the provisions of Section 58. However, doctors have an ethical and common law duty to give appropriate treatment to any patient (person) in an emergency situation and where it is indicated as a matter of urgent necessity. Any treatment may be given in this situation to save the patient's life, or to prevent a serious deterioration of his condition. A doctor or nurse might even be found to be negligent if he simply stood still and did nothing at all. His duty extends to patients who are informal and those detained under one of the short-term Sections of the Act which contains nothing to abrogate that duty. Section 62 is simply an 'exclusion Section', which removes the restrictions of Sections 57 and 58 allowing some of the treatments to be given to detained patients without formalities as a matter of urgency. Otherwise the common law duty applies.

ROBERT BLUGLASS

Chairman, PPC Working Party on the Mental Health Act All Saints' Hospital

Birmingham

\section{Lord Chancellor's Medical Visitors}

DEAR SIRS

Your readership may be interested to know that the British Medical Association, through my Committee, has been involved in protracted discussions with the Lord Chancellor's Department and the Treasury concerning the remuneration of Lord Chancellor's Medical Visitors in connection with the Court of Protection.

Until February of this year there were three established whole-time posts of Medical Visitor. A change of legislation brought about in 1981 resulted in a reduced workload and a change to part-time appointments. There are currently two Visitors in post with plans to expand the number by at least one in order to reduce the time spent in travelling.

Because the BMA has not yet concluded an agreement which it regards as satisfactory, we must advise Members against applying for one of the new part-time posts until they have first contacted me for further details.

J. R. A. Chawner Chairman, Private Practice Committee

British Medical Association

Tavistock Square, London WCI

\section{Report of the Advisory Council on the Misuse of Drugs}

DeAR SIRS

Debate continues about the recommendations of the DHSS Report of the Advisory Council on the Misuse of Drugs Treatment and Rehabilitation (HMSO, 1982). We believe that the full implementation of the recommendations would be disastrous.

In our Association, 'independent doctor' means a doctor working outside a hospital or drug dependence unit. About half our members are GPs in the NHS and about half are psychiatrists. We believe that independent doctors are now essential to the successful resolution of the country's problems in addiction control.

The subject of drug addiction has become surrounded by mystery and misrepresentation. We believe it should be 'normalized'. Most drug addicts are normal people leading normal lives. Their care should be part of the ordinary daily 